\title{
IS NECROPHYLUS ARENARIUS ROUX THE LARVA OF PTEROCROCE STOREYI WITHYCOMBE
}

\author{
By William MoRToN WheEler
}

Nearly a century ago, in 1833 , J. L. F. P. Roux, in a letter addressed to Baron Férussac and published in the "Annales des Sciences Naturelles" mentioned and figured a remarkable insect, with the prothorax continued anteriorly into an enormously elongate and attenuate "neck," broad mesothorax, metathorax and abdomen, long, slender legs and small head with falcate mandibles. It measured nearly $11 \mathrm{~mm}$. and was "found running over the sands which encumber the interior of tombs hollowed out in the rock of the environs of the pyramids of Gizeh," near Cairo, Egypt. To this insect which he believed "should necessarily constitute a new genus among the hexapod Aptera," Roux gave the name Necrophylus arenarius (p. 76). The editor (probably Audouin) in a foot-note asks whether it is not more probably the larva of some insect, "perhaps that of Mantispa or Raphidia." Turning to the explanation of the two illustrations (Figs. 3 and 4) on p. 78 and their legend on Pl. 7 we find in both places the name of the insect given as Necrophilus arenarius. This change in spelling is very probably due to the editor (Audouin), and has been followed by all the subsequent authors who have referred to the insect. The generic name thus becomes a homonym of Necrophilus (Coleopt.) Latreille (1929). But it is not improbable that Roux wished the name to signify "associated or allied with the dead," instead of "loving the dead." If this was his intention, we might have expected him to use the form "Necrophylius," but the Greeks seem occasionally to have preferred the shorter form "phylos" as in "emphylos." Be this as it may, however, our rules of nomenclature require us to return to Roux's original spelling of the 
generic name, and this precludes its homonymy with Necrophilus Latreille.

In 1857 Schaum, in the first article of the first volume of the "Berliner Entomologische Zeitschrift," gave a description and excellent figures of what he regarded as Roux's insect, with an account of the alimentary canal and nervous system, drawn from some 20 specimens which he had captured in 1852 in the dust of tombs at Beni-Hassan, near Cairo. Schaum was strongly of the opinion that the insect was a larval Nemoptera. Westwood had previously reproduced Roux's figure in the second volume of his "Introduction to the Modern Classification of Insects," (1840) and had ventured the suggestion that the insect from its size might either produce a Nemoptera, Bittacus or Panorpa." Within more recent years Roux's or Schaum's figures have been reproduced in various other general accounts of the Neuroptera, such as those of Sharp, Navas and MaxwellLefroy.

The mystery which has so long enveloped the affinities of Necrophylus has been recently dispelled by G. Storey, entomologist of the Egyptian Ministry of Agriculture, and C. B. Williams (Eltringham 1923, Withycombe 1923-b, 1924), who found it near Cairo, in the dust accumulated on the floors of desert caves or under rocky ledges and succeeded in rearing the imago. This proves to be a Crocine Nemopterid, to which Withycombe (1923a) has given the name Pterocroce storeyi. Storey reared a few adults from larvæ taken about 1915 from a cave some four miles from Wadi Digla, where Williams obtained his specimens in 1922. Eltringham and Withycombe have published excellent figures of the larva, (one of which is here reproduced as Fig. 1), and the latter has also described an allied form, Nina joppana, males and females of which had been reared in 1921 by Aharoni (Blair 1920-1921) from larvæ taken in the sand of caves near Jaffa, Palestine. The larva of this species closely resembles that of Pterocroce storeyi but has a distinctly shorter "neck."

Both Eltringham and Withycombe seem to believe that the introduction of the new name Pterocroce storeyi is justified for the insect reared by Storey and Williams. Eltring- 
ham offers the following comment on Roux's drawing of Necrophylus arenarius: "The drawing referred to is evidently incorrect in several details. The position of the front legs is wrong and the shape of the body is not fully indicated, whilst a slightly enlarged drawing of the head shows a structure of the mandibles and antennæ not found in the

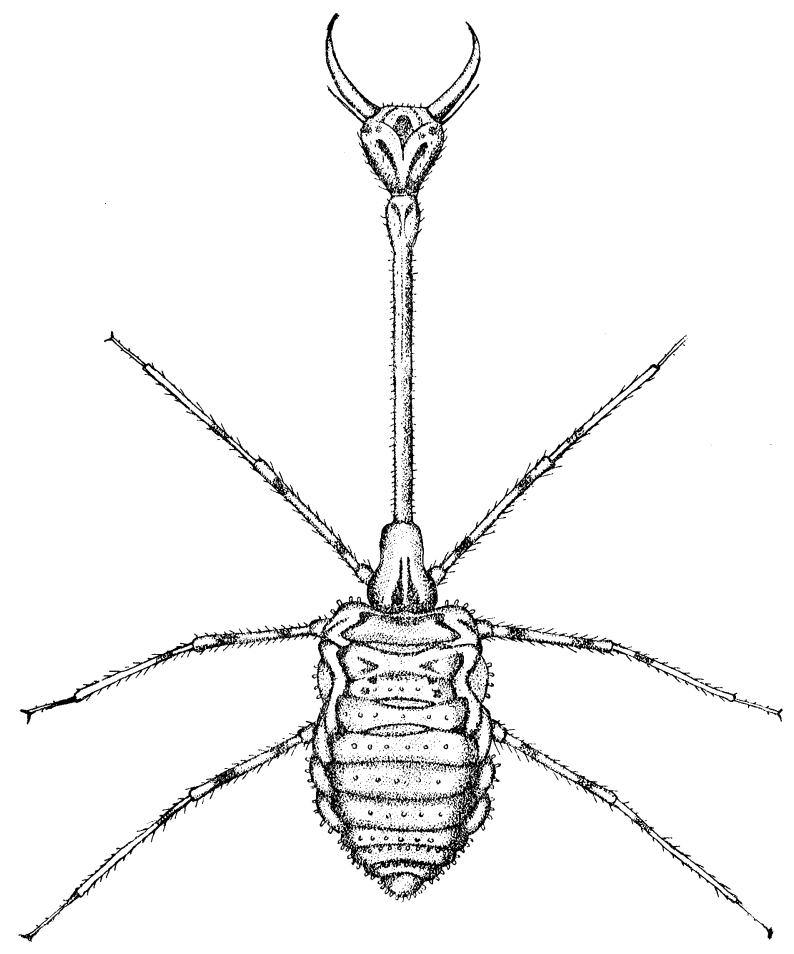

Fig. 1. Larva of Necrophylus arenarius Roux (Pterocroce storeyi Withycombe) After Eltringham.

specimens examined by the writer, nor evidently in those described by Schaum." And Withycombe disposes of Roux's species in a foot-note: "I am not able to identify this larva with Necrophilus arenarius Roux. Roux's figure and description are totally inadequate, and seeing that Nina cho- 
bauti McL. also occurs in the same locality (Wadi Digla), this might equally be Roux's Necrophilus. The larva of Nina joppana sp. $\mathrm{n}$. is also very similar to the present larva as will be seen." Neither of these statements seems to me to furnish adequate reasons for introducing the name Pterocroce storeyi. There are really two questions involved, namely: Is Roux's larva Necrophylus arenarius the same as Schaum's Necrophilus arenarius? and is Schaum's $N$. arenarius the same as Withycombe's Pterocroce storeyi? If both questions admit of an affirmative answer, Roux's and Withycombe's species are obviously identical.

The first question is the more complicated, since it involves a problem of fact and one of nomenclature. It is true that Roux's drawing is crude, but it was made on a journey and from an insect whose true affinities were quite unsusrected. Even the editor (Audouin) in the above-mentioned foot-note remarks that "the drawing by the author leaves much to be desired." But who expects drawings made nearly a century ago to represent minute structural details with the accuracy demanded by the present-day entomologist? The position of the forelegs and shape of the abdomen in Roux's Fig. 3, criticized by Eltringham, are of little significance because such distortions may be due to the method of mounting or the state of preservation. The more serious discrepancies in the enlarged head (Fig. 4), especially the swollen basal antennal joints and small hairs on the inner borders of the mandibles, are in all probability due to faulty observation. These characters are not indicated in the drawing of the whole specimen (Fig. 3), which would have to be regarded as the first and more authentic figure. It should also be noted that even in the excellent illustrations of Eltringham and Withycombe the joints of the very delicate antennæ beyond the first are not indicated, and an entomologist of the year 2030 might say that these organs consist of a single basal joint with a long apical bristle. There is really no basis for Withycombe's statement that Roux's larva may be the unknown larva of Nina chobauti, since the "neck" of $N$. joppana is distinctly shorter and it is therefore more probable that the congeneric chobauti would have a "neck" of the same or very similar dimensions. The fact that Wil- 
liams took a single female of chobauti "at light" at Wadi Digla is no evidence that Roux's specimen was of that species. It is certainly more probable that it belonged to the common larva in the same and other localities about Cairo and that larva is the one identified by Withycombe as Pterocroce storeyi. The nomenclatorial problem centers about Schaum's interpretation of Roux's larva. The German entomologist evidently entertained no doubt that his specimens belonged to the same species. He may therefore be said to have validated Roux's generic and specific names as those of his own specimens even if it can never be proved that the specimens taken at Gizeh and Beni Hassan are cospecific.

I believe the answer to the second question, that of the identity of Schaum's and Withycombe's larvæ, is even more clearly affirmative. In the rather extensive collection of larval and pupal Neuroptera accumulated by Dr. H. Hagen during his long association with the Museum of Comparative Zoology, I find two of the 20 larvæ collected by Schaum in 1852. One of them measures $8.5 \mathrm{~mm}$., and is therefore nearly full grown, the other $7.3 \mathrm{~mm}$. They bear Schaum's original label, with the remark: "Häufig auf dem Schutt der Felsengräber von Beni-Hassan, 400' über d. Nil, freilaufend. Schaum," and additional labels in Hagen's handwriting with an English rendering of the foregoing and " 223. Nemoptera sp.-Necrophilus arenarius Roux. Hagen pl. f." These specimens are mentioned by Hagen in his paper on the Nemopteridæ (1888). After expressing his opinion that the larva of $N$. arenarius described by Roux and Schaum is probably that of Nemoptera (Brachystoma) olivieri, he adds: "types of the larva are in my collection." On comparing these types, or paratypes as we should now call them, with Eltringham's and Withycombe's figures of the larval Pterocroce storeyi, I am quite unable to detect any differences, except in coloration. Withycombe figures and describes a more and a less pigmented "form" of larva, and Hagen's specimens are slightly paler than the latter. This, I am convinced, is due to bleaching by the alcohol in which the specimens have been preserved for nearly 78 years. I conclude, therefore, that Roux's, Schaum's and 
Withycombe's larvæ all belong to the same species of Crocine Nemopterid, which should bear the name Necrophylus arenarius (Roux) Schaum.

The Crocini obviously constitute a peculiar tribe of Nemopteridæ, with strongly marked larval and adult characters, both morphological and ethological. The adults are small, frail insects with a strongly produced beak-like front, short antennæ and very long, thread-like hind wings. The larvæ have the prothorax produced into a slender and elongate "neck" anteriorly but the attenuation and elongation of this region differ considerably in different genera, being very great in Necrophylus, less pronounced in Nina and much feebler in Croce, as shown by the observations of Maxwell-Lefroy (1909, 1910), Ghosh (1910), and Imms (1911) on the Indian Croce filipennis. Withycombe (1924) has been able to study the first instar larva of one of the true Nemopteras (N. bipennis) and has shown that it has a very short prothorax and neck, even shorter than in antlion (Myrmeleontid) larvæ.

Ethological observations on the Crocini show that they are to be regarded as cavernicolous insects. The larvæ of the species of Necrophylus and Nina, as we have seen, live in the dust and sand of tombs, caves and rock-cavities, and those of Croce filipennis are common in the dust that accumulates on the floors of disused rooms and bungalows, where they feed on Psocids, Lepismids, etc. The adult Crocini fly at dusk or, if during the day, in dark corners, within the confines of the caves, cavities or human dwellings. This is also true of the Spanish Josandreva sazi, which was found by Navas (1910) flying at dusk in the cavities of walls and especially in those containing sand or dust. In all probability the larvæ of this delicate insect lives and hunts its prey in these accumulations. The adults of the genus Nemoptera, however, live in the open and may fly by day. At any rate I took quite a number of $N$. bipennis flying or resting on the sparse vegetation of the sun-baked hills about Ronda, Spain (June 30,1925), at a considerable distance from walls or rock-cavities. The larvæ probably 
live in the dust or sand of the open fields like many of the Myrmeleontid larvæ that do not make pits.

\section{LITERATURE}

1920-21 Blair, K. G., (Larva of a Nemoptera sp.) Proc. S. London Ent. Nat. Hist. Soc. 1920, 21, p. 85.

1923 Eltringham, H. On the Larva of Pterocroce storeyi With. (Nemopteridæ) with additional notes by E. N. Willmer and C. B. Williams. Trans. Ent. Soc. London 1923, pp. 263-268, 1 fig. 1 pl.

1910 Ghosh, C. C. Croce filipennis Westw. Journ. Bombay Nat. Hist. Soc. 20, 1910 pp. 530-532, 1 pl.

1888 Hagen, H. Monograph of the Hemerobiidæ Part I Nemopteridæ. Proc. Boston Soc. Nat. Hist. 23, 1888, pp. 250-269.

1911 Imms, A. D. Contributions to a Knowledge of the Structure and Biology of Some Insects. I. On the Life-History of Croce filipennis Westw. Trans. Linn. Soc. London, Zoology (2) 11, pp. 151-160, 1 pl.

1909 MAXWELL-LeFroY, H. Indian Insect Life. Calcutta and Simla, Thacker, Spink \& Co. 1909.

1910 Maxwell-Lefroy, H. Entomological Notes. (b) The Indian Nemopterid and its Food. Journ. Bombay Nat. Hist. Soc. 19, 1910, pp. 1005-1007, 7 fig.

1910 Navas, L. Monografia de los Nemoptéridos (Insectos Neuropteros) Mem. Real. Acad. Ciencias y Artes Barcelona (3) 8, 1910, pp. 341-408, 24 figs. 1 pl.

1833 Roux, J. L. F. P. Lettre relative a divers Coquilles, Crustacés, Insectes, Reptiles et Oiseaux observés en Egypte, addressée par M. Roux a M. le baron Férussac. Ann. Sc. Nat. 28, 1833 pp. 72-78, 1 pl.

1857 Schaum, H. R. Necrophilus arenarius Roux, die mutmasliche Larve von Nemoptera. Berlin Ent. Zeitschr. 1857, pp. 1-9, Pl. 1, Fig. 1. 
1840 Westwood, J. O. Introduction to the Modern Classification of Insects. Vol. 2. London, Longman \& Co. 1840.

1923-a Withycombe, C. L. A New Egyptian Nemopterid (Neuroptera). The Entomologist 56, 1923, p. 141.

1923-b Wiтнycombe, C. L. Systematic Notes on the Crocini (Nemopteridæ) with Descriptions of New Genera and Species. Trans. Ent. Soc. London 1923, pp. 269-287, 2 pls.

1924 Wiтнyсомвe, C. L. Some Aspects of the Biology and Morphology of the Neuroptera with Special Reference to the Immature Stages and their possible Phylogenetic Significance. Trans. Ent. Soc. London 1924 pp. 303-411, 6 pls. 

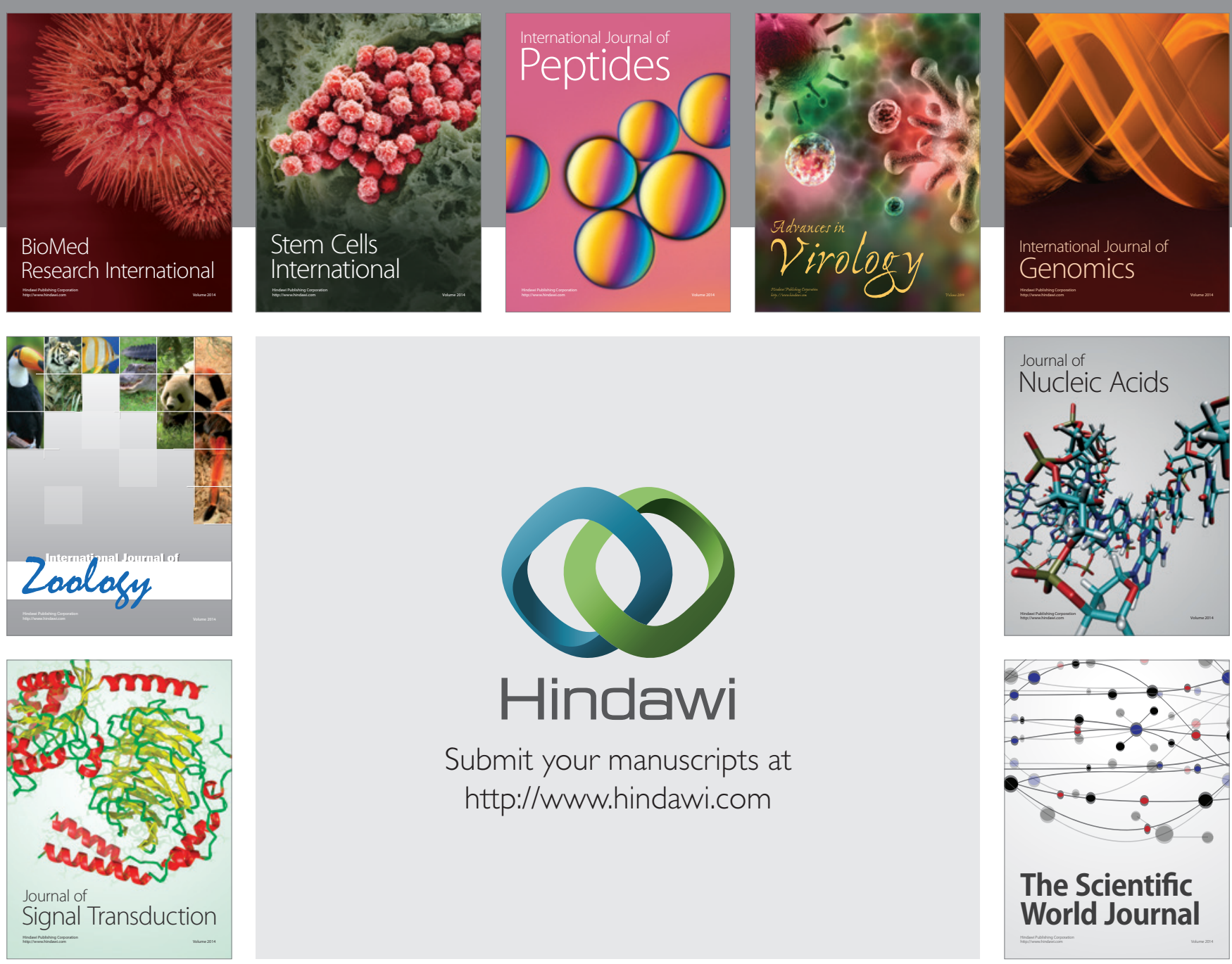

Submit your manuscripts at

http://www.hindawi.com
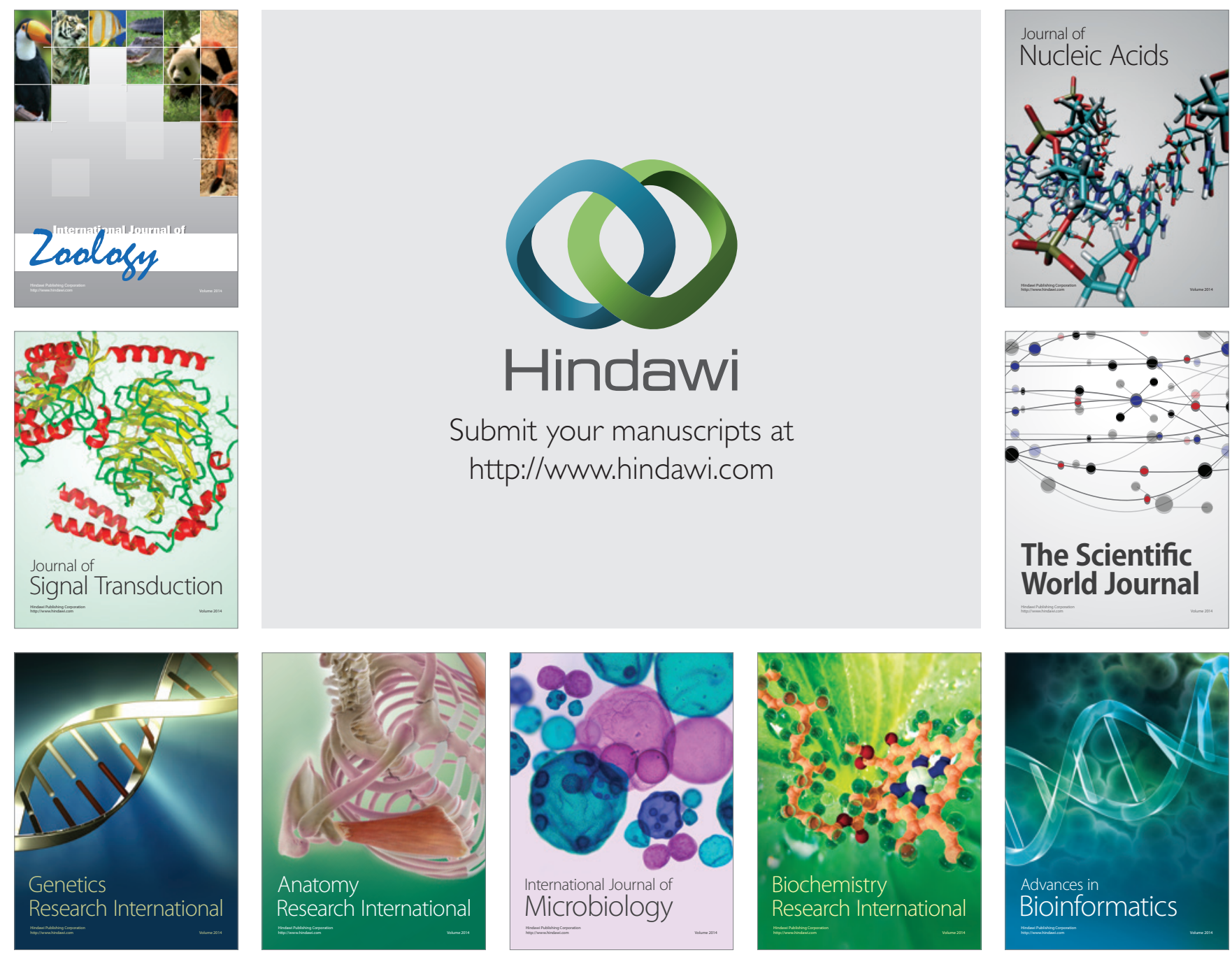

The Scientific World Journal
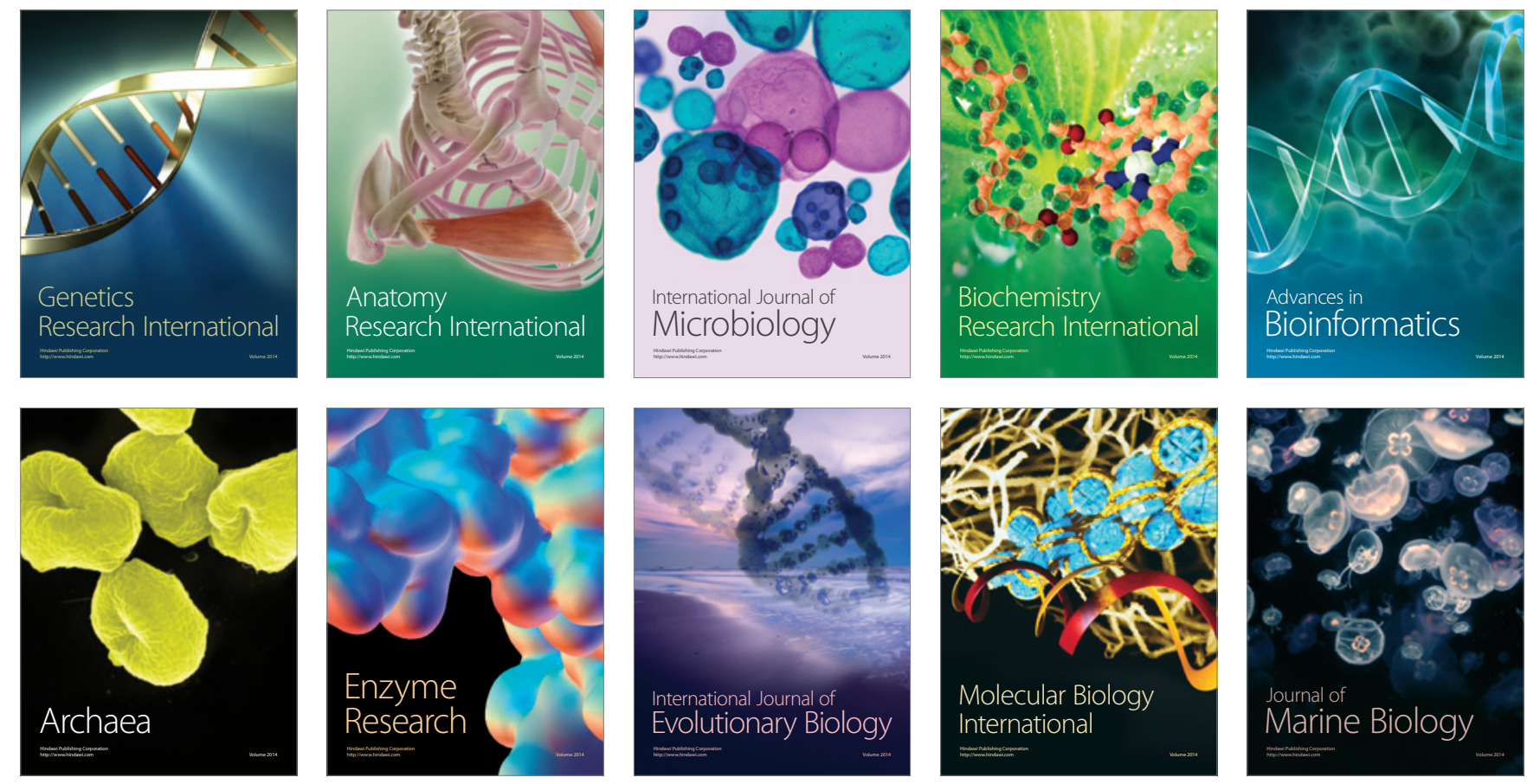